\title{
Syngas Production from Pyrolysis of Nine Composts Obtained from Nonhybrid and Hybrid Perennial Grasses
}

\author{
Adéla Hlavsová, ${ }^{1}$ Agnieszka Corsaro, ${ }^{1}$ Helena Raclavská,, ${ }^{1,2}$ Dagmar Juchelková, ${ }^{1,3}$ \\ Hana Škrobánková, ${ }^{2}$ and Jan Frydrych ${ }^{4}$ \\ ${ }^{1}$ ENET-Energy Units for Utilization of Non-Traditional Energy Sources, VŠB-Technical University of Ostrava, 17. listopadu 15/2172, \\ 70833 Ostrava-Poruba, Czech Republic \\ ${ }^{2}$ Institute of Geological Engineering, Faculty of Mining and Geology, VŠB-Technical University of Ostrava, 17. listopadu 15/2172, \\ 70833 Ostrava-Poruba, Czech Republic \\ ${ }^{3}$ Department of Energy, Faculty of Mechanical Engineering, VŠB-Technical University of Ostrava, 17. listopadu 15/2172, \\ 70833 Ostrava-Poruba, Czech Republic \\ ${ }^{4}$ OSEVA PRO s.r.o., Grass Research Institute, Rožnov-Zubří, Hamerská 698, 75654 Zubří, Czech Republic
}

Correspondence should be addressed to Adéla Hlavsová; adela.hlavsova@vsb.cz

Received 6 March 2014; Revised 9 June 2014; Accepted 13 June 2014; Published 1 July 2014

Academic Editor: Bin Cao

Copyright (C) 2014 Adéla Hlavsová et al. This is an open access article distributed under the Creative Commons Attribution License, which permits unrestricted use, distribution, and reproduction in any medium, provided the original work is properly cited.

\begin{abstract}
A pyrolysis of compost for the production of syngas with an explicit $\mathrm{H}_{2} / \mathrm{CO}=2 \mathrm{or}_{2} / \mathrm{CO}=3$ was investigated in this study. The composts were obtained from nonhybrid (perennial) grasses (NHG) and hybrid (perennial) grasses (HG). Discrepancies in $\mathrm{H}_{2}$ evolution profiles were found between NHG and HG composts. In addition, positive correlations for NHG composts were obtained between (i) $\mathrm{H}_{2}$ yield and lignin content, (ii) $\mathrm{H}_{2}$ yield and potassium content, and (iii) $\mathrm{CO}$ yield and cellulose content. All composts resulted in $\mathrm{H}_{2} / \mathrm{CO}=2$ and five of the nine composts resulted in $\mathrm{H}_{2} / \mathrm{CO}=3$. Exceptionally large higher heating values (HHVs) of pyrolysis gas, very close to HHVs of feedstock, were obtained for composts made from mountain brome (MB, $16.23 \mathrm{MJ} / \mathrm{kg})$, hybrid Becva (FB, 16.45 MJ $/ \mathrm{kg}$ ), and tall fescue (TF, $17.43 \mathrm{MJ} / \mathrm{kg}$ ). The $\mathrm{MB}$ and FB composts resulted in the highest syngas formation with $\mathrm{H}_{2} / \mathrm{CO}=2$, whereas TF compost resulted in the highest syngas formation with $\mathrm{H}_{2} / \mathrm{CO}=3$.
\end{abstract}

\section{Introduction}

The pressing demands for greater generation of energy at a lower cost, associated with a diminution of greenhouse gases (GHG) emission, have compelled researchers to expand their search for an energy source outside conventional and primary energy sources, such as fossil fuels. This pursuit is facilitated by the utilization of renewable energy sources and based on Directive 2001/77/EC of the European Parliament that must consist of 13\% of the total energy consumption by 2020 in the Czech Republic [1]. Biomass, specifically energy crops, is of particular interest among these renewable energy resources. It has been predicted that by 2050 energy crops will have the potential to supply around 200-400 EJ/year at a competitive cost [2], and up to $161 \mathrm{EJ} /$ year of the 200-400 EJ/year range will come from projected surplus cropland and grassing areas [3]. The competitive costs are based upon the incentives made available through the scheme for energy crops according to the Article 88 of Regulation (EC) No. 1782/2003 [4]. The preference of energy crops over other types of biomass for energy generation is due to their (i) higher productivity, (ii) lower investment cost, (iii) low environmental maintenance, (iv) short time between plantation and harvesting, and (v) high energy values [5-7]. Another reason for which energy crops, in particular grasses, are being considered as a source of energy is the overproduction of grass and/or hay from permanent grasslands. This overproduction is a result of a diminution of livestock. According to the Czech Statistical Office, the land used for agriculture reached 959,131 ha with harvest of $3.22 \mathrm{t} / \mathrm{ha}$ in 2012 [8]. Comparatively, livestock numbers decreased since 1990 by $60.78 \%$ for cattle and 66.74\% for pigs reaching 1375 cattle and 1593 pigs in 2012 [9]. Therefore, it is necessary to find an appropriate technology to manage and utilize the excess of grass. 
The number of technologies available to convert biomass to energy has developed greatly in recent years and they are focused in general on production of synthesis gas (syngas) $[10,11]$. Syngas which is a mixture of hydrogen $\left(\mathrm{H}_{2}\right)$ and carbon monoxide (CO) can then be directly converted to energy through combustion or to a variety of fuels: (i) liquid hydrocarbons from methanol, (ii) liquid hydrocarbons through Fischer-Tropsch synthesis, and (iii) synthetic natural gas (SNG) $[11,12]$. The selective conversion of syngas to liquid hydrocarbons or SNG requires, however, specific ratios of $\mathrm{H}_{2}$ to $\mathrm{CO}$ in the amount of 2 or 3, respectively [12]. Obtaining those explicit values is not a straightforward task as the yields of produced noncondensable gases depend on several factors such as raw material composition and operating conditions of the converting process [13-15].

Two methods in particular have been reported in the literature that convert biomass to syngas, namely, gasification and pyrolysis. Gasification is a thermochemical method which converts a variety of biomass in an oxygen environment. Typical reactions involved in any gasification process are the reactions using oxygen $\left(\mathrm{O}_{2}\right)$ (combustion) represented by (1) and (2), the reverse Boudouard reaction represented by (3), the water-gas reaction represented by (4), and the water-gas shift (WGS) reaction represented by $(5)[16,17]$ :

Partial oxidation:

$2 \mathrm{C}+\mathrm{O}_{2} \longrightarrow 2 \mathrm{CO} \Delta H_{r}^{0}=-222 \mathrm{~kJ} / \mathrm{mol}$

Oxidation of carbon:

$\mathrm{C}+\mathrm{O}_{2} \longrightarrow \mathrm{CO}_{2} \quad \Delta H_{r}^{0}=-394 \mathrm{~kJ} / \mathrm{mol}$

Revers Boudouard reaction:

$\mathrm{C}+\mathrm{CO}_{2} \longrightarrow 2 \mathrm{CO} \Delta H_{r}^{0}=173 \mathrm{~kJ} / \mathrm{mol}$

Water-gas reaction:

$\mathrm{C}+\mathrm{H}_{2} \mathrm{O} \longrightarrow \mathrm{CO}+\mathrm{H}_{2} \quad \Delta H_{r}^{0}=131 \mathrm{~kJ} / \mathrm{mol}$

Water-gas shift reaction:

$$
\mathrm{CO}+\mathrm{H}_{2} \mathrm{O} \longrightarrow \mathrm{CO}_{2}+\mathrm{H}_{2} \quad \Delta H_{r}^{0}=-41 \mathrm{~kJ} / \mathrm{mol}
$$

As a consequence of these reactions, a wide range of $\mathrm{H}_{2} / \mathrm{CO}$ ratios (0.45-2) are obtained [18]. Pyrolysis on the other hand is a process in which biomass undergoes thermal degradation in an oxygen-free atmosphere. The final products are pyrolysis solid, liquid, and gas containing mainly $\mathrm{CO}$, carbon dioxide $\left(\mathrm{CO}_{2}\right), \mathrm{H}_{2}$, and lower hydrocarbons $\left(\mathrm{C}_{1}-\mathrm{C}_{3}\right)$. The remaining reactions involved in the process apart from previously mentioned reactions (3), (4), and (5) are the following [19]:

Steam reforming of methane:

$\mathrm{CH}_{4}+\mathrm{H}_{2} \mathrm{O} \longrightarrow \mathrm{CO}+3 \mathrm{H}_{2} \quad \Delta H_{r}^{0}=206 \mathrm{~kJ} / \mathrm{mol}$

Steam reforming of tar:

$$
\begin{aligned}
& \mathrm{C}_{n} \mathrm{H}_{m} \mathrm{O}_{p}+(2 n-p) \mathrm{H}_{2} \mathrm{O} \\
& \longrightarrow n \mathrm{CO}_{2}+(1 / 2 m+2 n-p) \mathrm{H}_{2} \quad \Delta H_{r}^{0} \geq 0 \mathrm{~kJ} / \mathrm{mol}
\end{aligned}
$$

Thermal cracking:

$$
\mathrm{C}_{n} \mathrm{H}_{m} \longrightarrow \mathrm{C}_{n-x} \mathrm{O}_{m-y}+\mathrm{H}_{2}+\mathrm{CH}_{4}+\mathrm{C} \quad \Delta H_{r}^{0} \geq 0 \mathrm{~kJ} / \mathrm{mol}
$$

Methanation:

$$
\mathrm{C}+2 \mathrm{H}_{2} \longrightarrow \mathrm{CH}_{4} \quad \Delta H_{r}^{0}=-75 \mathrm{~kJ} / \mathrm{mol}
$$

The obtained $\mathrm{H}_{2} / \mathrm{CO}$ ratios are dependent on pyrolysis temperature and increase as the latter increases [15, 20-22]. Their values are, however, somewhat lower (i.e., 0.1-1.42 in the $500-1000^{\circ} \mathrm{C}$ range) when compared to the values obtained from biomass gasification $[15,20,22]$. In addition, in order to make syngas suitable for commercial application (i.e., reduce economic investment and improve its quality (obtain an appropriate $\mathrm{H}_{2} / \mathrm{CO}$ ratio, ipso facto increase $\mathrm{H}_{2}$ formation)), the obtained gas mixture needs to be cleaned and processed $[18,23]$. These requirements can be avoided or minimized by pretreatments of biomass raw material such as composting $[10,24]$.

Composting is a naturally occurring, biological decomposition process in which bacteria, fungi, and other microorganisms break down the organic matter into a more stable form called compost $[10,24,25]$. The process occurs in two stages. The first stage (i.e., organic matter degradation) results in the formation of $\mathrm{CO}_{2}, \mathrm{NH}_{3}, \mathrm{H}_{2} \mathrm{O}$, saccharides, and humic substances (fulvic and humic acids) with emission of heat $[23,26]$. The second stage involves the maturation and stabilization of formed material [26]. As a result of both stages, the newly formed organic matter has a different chemical composition, ipso facto thermal behavior $[10,23$, $24,27]$. Composting reduces the content of two of the major biomass components, namely, cellulose and hemicellulose, while increasing the content of lignin [10, 23, 24]. These changes are of particular importance, since lignin is the component responsible for the highest $\mathrm{H}_{2}$ and $\mathrm{CH}_{4}$ formation, hemicellulose is responsible for the highest $\mathrm{CO}_{2}$ emission, and cellulose is responsible for the highest $\mathrm{CO}$ release [2831]. Yang et al. [29] examined pyrolysis characteristics of lignin, cellulose, and hemicellulose and concluded that the main source of $\mathrm{H}_{2}$ release was lignin. Lignin resulted in four times more emission of $\mathrm{H}_{2}$ than cellulose and three times more than hemicellulose [29]. Similar results were obtained by Barneto et al. [31] who extended the investigation of $\mathrm{H}_{2}$ origin and reported that although most of $\mathrm{H}_{2}$ is emitted from thermal degradation of lignin, three times more $\mathrm{H}_{2}$ is released from charring than from volatilization of lignin. In addition, hemicellulose is the least stable from the three biochemical components and, therefore, reacts at the lowest temperatures, followed by cellulose and lignin [32]. Consequently, the changes in the chemical composition due to composting result in the changes in pyrolysis gaseous products. That is, a mixture of $\mathrm{H}_{2}$ and $\mathrm{CO}$ becomes the primary product, not a mixture of $\mathrm{CO}_{2}$ and $\mathrm{CO}$ which are the major products of biomass pyrolysis $[21,28]$. For this reason also, the composts obtained from perennial grasses rather than grasses alone are considered as a feedstock for pyrolysis experiments in this research. 
TABLE 1: Names and abbreviations of composts.

\begin{tabular}{lcc}
\hline Grass type & Grass name & Compost abbreviation \\
\hline & Redtop-Rožnovsḱ (Agrostis gigantea Roth) & $\mathrm{R}$ \\
& Reed canary grass-Chrastava (Phalaris arundinacea L.) & RC \\
Nonhybrid & Tall fescue-Kora (Festuca arundinacea Schreb.) & TF \\
& Tall oat grass-Rožnovský (Arrhenatherum elatius L.) & TO \\
& Mountain brome-Tacit (Bromus marginatus Nees ex Steud.) & MB \\
& Mixture of clover (Trifolium pratense) & MC \\
Hybrid & Festulolium Perun & FP \\
& Festulolium Becva & FB \\
\hline
\end{tabular}

TABLe 2: Proximate and ultimate analyses of composts.

\begin{tabular}{|c|c|c|c|c|c|c|c|c|c|}
\hline \multirow{2}{*}{ Compost } & \multicolumn{4}{|c|}{ Ultimate analysis (wt\%) } & \multicolumn{4}{|c|}{ Proximate analysis (wt\%) } & \multirow{2}{*}{$\mathrm{HHV}(\mathrm{MJ} / \mathrm{kg})$} \\
\hline & $\mathrm{C}$ & $\mathrm{N}$ & $\mathrm{H}$ & $\mathrm{O}^{c}$ & Moisture $^{\mathrm{d}}$ & Volatile matter $^{\mathrm{a}}$ & $\operatorname{Ash}^{\mathrm{a}}$ & Fixed carbon ${ }^{\mathrm{a}, \mathrm{c}}$ & \\
\hline $\mathrm{R}$ & 47.24 & 0.91 & 6.6 & 45.25 & 4.54 & 74.88 & 09.83 & 15.29 & 17.45 \\
\hline $\mathrm{RC}$ & 46.43 & 0.49 & 6.88 & 46.2 & 6.29 & 76.02 & 07.6 & 16.38 & 17.61 \\
\hline $\mathrm{TF}$ & 46.39 & 0.56 & 7.09 & 45.97 & 4.38 & 74.17 & 10.3 & 15.53 & 17.3 \\
\hline TO & 48.84 & 1.11 & 6.7 & 43.34 & 5.66 & 72.3 & 12.72 & 14.98 & 17.53 \\
\hline MB & 47.9 & 0.59 & 7.14 & 44.37 & 5.87 & 73.1 & 11.42 & 15.48 & 17.21 \\
\hline $\mathrm{MC}$ & 44.43 & 0.96 & 5.93 & 48.68 & 5.23 & 71.98 & 13.3 & 14.72 & 16.69 \\
\hline FP & 46.5 & 0.83 & 6.6 & 46.07 & 6.12 & 73.29 & 10.52 & 16.19 & 18.29 \\
\hline FB & 44.64 & 0.64 & 6.42 & 48.3 & 5.5 & 75.73 & 07.95 & 16.32 & 18.11 \\
\hline FL & 48.11 & 0.77 & 6.52 & 44.6 & 5.68 & 74.26 & 08.94 & 16.8 & 18.21 \\
\hline
\end{tabular}

${ }^{\mathrm{a}}$ Dry basis.

${ }^{\mathrm{b}}$ Ash free.

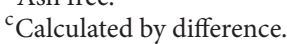

${ }^{\mathrm{d}}$ As received.

The purpose of this study was to compare the composition, yields, and evolution of gaseous products from pyrolysis of nine composts. The examined composts were obtained from two types of perennial grasses: nonhybrid and hybrid. The main objective was selective formation of syngas with an explicit $\mathrm{H}_{2} / \mathrm{CO}$ ratio in the amount of $2: 1$ or $3: 1$.

\section{Materials and Methods}

2.1. Materials. Nine composts made from perennial grasses (six nonhybrid grasses (NHG) and three hybrid grasses (HG)) were investigated in this study. The grass crops were obtained from OSEVA PRO s.r.o., Grass Research Institute, Rožnov-Zubří, CZ. The names and abbreviation of the composts examined are displayed in Table 1.

2.2. Composting. The composting experiments were carried out at the Institute of Geological Engineering, VŠBTechnical University of Ostrava (VŠB-TU Ostrava), CZ. The nine perennial grasses were finely chopped $(<2 \mathrm{~cm})$ and mechanically mixed with sawdust and soil in the ratio of $4: 2: 1$ in order to obtain the appropriate $\mathrm{C} / \mathrm{N}$ ratio. The composting of each blend (perennial grass, sawdust, and soil) was conducted in a microcomposter (NM125, NatureMill) for
10 days, whereas the maturation of composts was carried out for 14 days.

2.3. Chemical Characterization of Composts. All nine composts were subjected to proximate and ultimate analyses. The following standard test methods were applied: CSN EN 15402 (volatile matter), CSN EN 15403 (ash), CSN EN 15104 (carbon $(\mathrm{C})$, nitrogen $(\mathrm{N})$, and hydrogen $(\mathrm{H})$ ), and CSN EN 15400 (higher heating value (HHV)). The summarized results are presented in Table 2 . The biochemical components were determined according to the CSN EN ISO 13906 standard test method (lignin) and the method described by Kačík and Solár [33] (cellulose and hemicellulose). Humic acids (HA) and fulvic acids (FA) were extracted from composts according to the method described by Swift [34]. In addition, analysis of water-soluble alkali was conducted according to the EN 15105 standard test method. The summarized results are shown in Table 3 .

2.4. Pyrolysis Experiments. The pyrolysis experiments were conducted in a stainless steel fixed bed reactor equipped with an electric heater (Parr). The temperature of the heater was controlled by a temperature controller (Parr, 4836 controller), while the reaction temperature was monitored by a Ktype thermocouple. The experiments were carried out in 
TABLE 3: Biochemical components, humic to fulvic acids ratio, and water-soluble alkali contents of composts.

\begin{tabular}{|c|c|c|c|c|c|c|}
\hline Compost & Lignin (wt $\%)$ & Cellulose (wt\%) & Hemicellulose (wt\%) & HA/FA & $\mathrm{Na}(\mathrm{mg} / \mathrm{g})$ & $\mathrm{K}(\mathrm{g} / \mathrm{kg})$ \\
\hline $\mathrm{R}$ & 37.47 & 43.07 & 19.07 & 2.63 & 1.4 & 7.76 \\
\hline $\mathrm{RC}$ & 34.04 & 51.71 & 02.51 & 2.57 & 4.92 & 3.44 \\
\hline $\mathrm{TF}$ & 36.27 & 51.49 & 06.99 & 2.58 & 1.16 & 4.71 \\
\hline TO & 38.2 & 46.2 & 17.92 & 3.13 & 1.51 & 7.7 \\
\hline $\mathrm{MB}$ & 30.48 & 55.41 & 05.98 & 2.58 & 2.09 & 3.93 \\
\hline MC & 38.24 & 43.62 & 09.07 & 3.12 & 3.01 & 7.76 \\
\hline FP & 34.66 & 54.75 & 07.18 & 2.87 & 4.42 & 7.86 \\
\hline $\mathrm{FB}$ & 36.54 & 53.47 & 07.78 & 2.58 & 1.35 & 2.87 \\
\hline FL & 34.75 & 50.28 & 05.77 & 2.57 & 1.12 & 6.7 \\
\hline
\end{tabular}

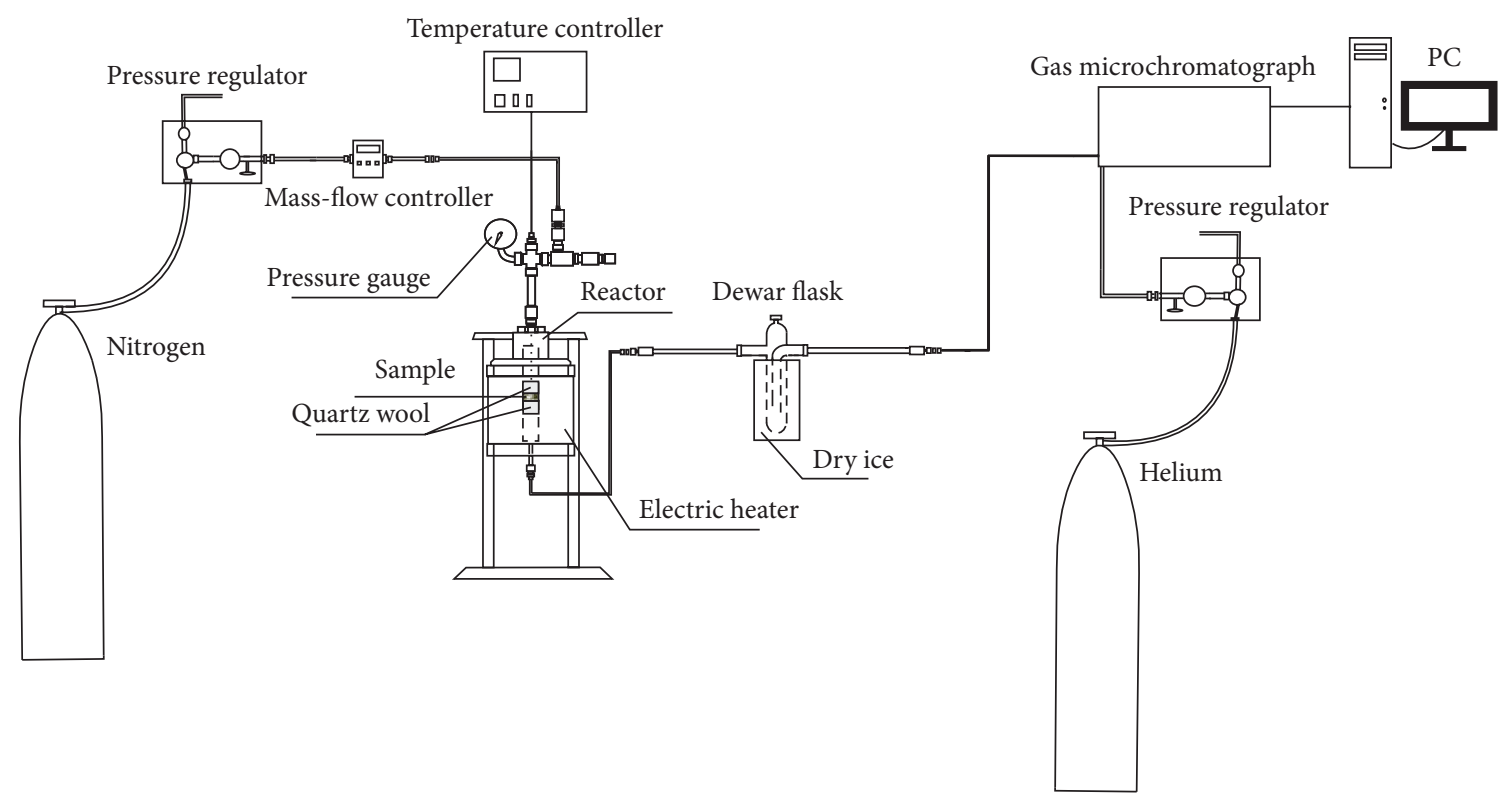

FIGURE 1: Experimental setup.

$\mathrm{N}_{2}$ atmosphere and the flow of gas was controlled by a mass- flow controller (SIERRA C100 Serie, Smart-Trak). The experimental setup is presented in Figure 1. For all pyrolysis experiments, $0.5 \mathrm{~g}$ of compost was loaded into the reactor and heated to a final temperature of $700^{\circ} \mathrm{C}$. The flow of $\mathrm{N}_{2}$ was maintained at $20 \mathrm{smL} / \mathrm{min}$ for all experiments. The experiments were considered completed when $\mathrm{N}_{2}$ was the only gas detected by online gas chromatography (GC).

2.5. Analysis of Gas Product. The noncondensable pyrolysis product was analyzed by online 2-channel GC (Agilent 3000) equipped with thermal conductivity detectors. The channels were equipped with the following columns: Molsieve for separation of $\mathrm{H}_{2}, \mathrm{~N}_{2}, \mathrm{CO}$, and $\mathrm{CH}_{4}$ and PLOT $\mathrm{U}$ for separation of $\mathrm{CO}_{2}, \mathrm{C}_{2}$, and $\mathrm{C}_{3}$.

2.6. Statistical Analysis. The relationships between components of chemical analyses and pyrolysis gaseous products yields were tested by bivariate correlation analysis, specifically Pearson's correlations. SPSS 17 statistical software was applied.

\section{Results and Discussion}

3.1. Gas Yield and Evolution. The yield of gaseous products obtained from pyrolysis of NHG and HG composts referred to as a gram of compost used is presented in Figure 2. The highest yield of pyrolysis gaseous products among NHG composts $(328.81 \mathrm{~mL} / \mathrm{g}$, also the highest yield among all composts pyrolyzed) was obtained for RC compost, whereas the lowest yield of pyrolysis gaseous products $(281.74 \mathrm{~mL} / \mathrm{g})$ among NHG composts was obtained for MC compost. The highest pyrolysis gas yield among HG composts was obtained for FL compost $(286.41 \mathrm{~mL} / \mathrm{g})$, whereas the lowest pyrolysis gas yield was obtained for FP compost $(251.77 \mathrm{~mL} / \mathrm{g})$ which also exhibited the lowest gas yield among all composts examined. The yield of pyrolysis gas decreased in the following order: $\mathrm{RC}>\mathrm{R}>\mathrm{TF}>\mathrm{TO}>\mathrm{MB}>\mathrm{MC}$ for composts made from nonhybrid grasses and FL $>$ FB $>$ FP for composts made from hybrid grasses.

Figure 3 shows the evolution profiles of released pyrolysis gas as a function of temperature. Figure 3(a) presents the evolution profiles of gas released during pyrolysis of NHG composts, while Figure 3(b) shows the evolution profiles of 


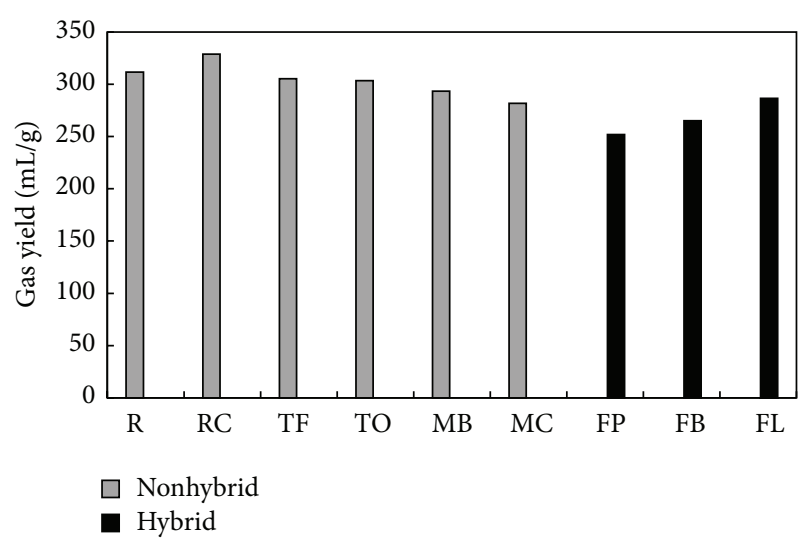

FIgURE 2: Total gas yield of composts.

gas released during pyrolysis of HG composts. The emission of noncondensable pyrolysis gases at temperature below $500^{\circ} \mathrm{C}$ is related in majority to degradation of the biochemical structures of compost as well as humic substances formed during the composting process $[21,23,35,36]$, whereas the release of gases at temperature $>500^{\circ} \mathrm{C}$ is likely associated with secondary reactions of char formed from biochemical components or humic substances [21, 23, 28, 35, 36]. In general, pyrolysis gases began to release at $170^{\circ} \mathrm{C}$ for all compost samples examined which is equivalent to the beginning of thermal degradation of hemicellulosic fraction [23]. The distinction was only observed for the pyrolysis experiment conducted on compost made from hybrid grass (FB) for which a beginning of gas evolution at $247^{\circ} \mathrm{C}$ was observed. Apart from TO compost which exhibited a three-stage evolution profile (three peaks were observed), all composts investigated resulted in two-stage evolution profiles (two peaks were observed). The composts made from nonhybrid grasses exhibited the maximum of the first peak at temperature range of $315-430^{\circ} \mathrm{C}$ which is a typical temperature range of thermal degradation of cellulose fraction $[29,30,37]$. The maximum of the second peak was observed at $472^{\circ} \mathrm{C}$ for $\mathrm{TF}$ compost, $508^{\circ} \mathrm{C}$ for R, RC, and $\mathrm{MC}$ composts, and $539^{\circ} \mathrm{C}$ for $\mathrm{TO}$ and $\mathrm{MB}$ composts and can be mainly attributed to thermal degradation of lignin and secondary reactions of chars and liquids [23, 29, 30, 37]. The third peak observed for TO compost was detected at $588^{\circ} \mathrm{C}$ and is also likely due to thermal degradation of lignin and secondary reactions of chars and liquids [23, 29, 30,37]. As previously mentioned, composts made from hybrid grasses resulted in two-stage gas evolution profiles as well, although more noticeable shifts in the peaks maximum were observed. Specifically, a shift from maximum at $315^{\circ} \mathrm{C}$ to maximum at $377^{\circ} \mathrm{C}$ was observed for $\mathrm{FP}, \mathrm{FB}$, and FL composts, respectively, and a shift from maximum at $430^{\circ} \mathrm{C}$ to maximum at $472^{\circ} \mathrm{C}$ and to maximum at $539^{\circ} \mathrm{C}$ for the second peak was observed for FP, FL, and FB composts, correspondingly. The change of peaks maximum noted for the FB composts is likely due to the delay of starting point of pyrolysis gas release.

3.2. Pyrolysis Gas Composition. The yields of major pyrolysis gaseous products $\left(\mathrm{H}_{2}, \mathrm{CO}_{2}, \mathrm{CO}\right.$, and $\left.\mathrm{CH}_{4}\right)$ from grass composts are presented in Figure 4. Other products such as short-chain hydrocarbons (i.e., $\mathrm{C}_{2}$ and $\mathrm{C}_{3}$ ) were also detected but in sizably lower amounts (less than $1 \mathrm{vol} \%$ ) and will not be discussed. Figure 4(a) shows yields of NHG composts gaseous products, whereas Figure 4(b) shows yields of HG composts gaseous products. The yields were calculated at $700^{\circ} \mathrm{C}$ (after $112 \mathrm{~min}$ ) and at $\mathrm{N}_{2}$ free-vol\%. Among NHG composts, MC compost resulted in the highest production of $\mathrm{H}_{2}$ (62.17 vol\%), the lowest formation of CO (12.74 vol\%) and $\mathrm{CH}_{4}(5.10 \mathrm{vol} \%)$, and the second lowest formation of $\mathrm{CO}_{2}$ (18.93 vol\%). The lowest yield of $\mathrm{H}_{2}(48.32 \mathrm{vol} \%)$ was observed for $\mathrm{MB}$ compost and as expected it also resulted in the highest $\mathrm{CO}(21.34 \mathrm{vol} \%)$ and $\mathrm{CH}_{4}(8.01 \mathrm{vol} \%)$ formation and a moderately high formation of $\mathrm{CO}_{2}(20.30 \mathrm{vol} \%)$. The majority of these observations are directly related to the biochemical composition of examined composts and the contents of water-soluble alkali. Specifically, lignin, cellulose, and potassium $(\mathrm{K})$ contents were found to be associated with $\mathrm{H}_{2}$ as well as $\mathrm{CO}$ and $\mathrm{CH}_{4}$ formation. A positive correlation was observed between $\mathrm{H}_{2}$ yield and lignin $(R=0.916$, $P<0.05)$, and stronger negative correlations were observed between CO yield and lignin $(R=-0.974, P<0.01)$ and between $\mathrm{CH}_{4}$ yield and lignin $(R=-0.929, P<0.01)$. The relationship between $\mathrm{H}_{2}$ and lignin is consistent with the results obtained by Barneto et al. [10] who examined the effect of Leucaena and tagasaste composts on the production of volatiles from pyrolysis and reported $75 \mathrm{wt} \%$ production of $\mathrm{H}_{2}$ from lignin. A positive correlation was also observed between $\mathrm{H}_{2}$ yield and $\mathrm{K}$ content $(R=0.750, P<0.1)$ and negative correlations were obtained between $\mathrm{CO}$ and $\mathrm{CH}_{4}$ yields and $\mathrm{K}$ content $(R=-0.901, P<0.05$ and $R=$ $-0.742, P<0.1$, correspondingly). Negative relationships between $\mathrm{K}$ content and $\mathrm{CO}$ and $\mathrm{CH}_{4}$ were likewise observed by Couhert et al. [38] who reported that mineral matter can influence pyrolysis reactions occurring inside the component's particle and decrease the formation of aforementioned gases. As previously mentioned, these correlations can also be explained by the occurrence of char gasification reactions ((4) and (5)) which are likely to be a result of combination of lignin and $\mathrm{K}$ contents. A higher lignin content is associated with a higher K content (i.e., Pearson's correlation coefficient between lignin and $\mathrm{K}$ content was $0.832, P<0.05)[28,39]$. Potassium, on the other hand, is known to be an effective catalyst for char gasification [20,24,39]. Both $\mathrm{MC}$ and $\mathrm{MB}$ composts have shown the highest and the lowest lignin and $\mathrm{K}$ contents which would explain their $\mathrm{H}_{2}$ and $\mathrm{CO}$ yields, the highest and lowest for MC compost, and the opposite for $\mathrm{MB}$ compost, respectively. As previously noted, the formation of $\mathrm{H}_{2}$ in majority from charring reactions was also confirmed by Barneto et al. [10]. Opposite correlations to those observed between lignin content and $\mathrm{CO}, \mathrm{CH}_{4}$, and $\mathrm{H}_{2}$ yields were found for cellulose. That is, a negative correlation was calculated between $\mathrm{H}_{2}$ yield and cellulose content $(R=-0.860, P<$ $0.05)$, and positive correlations were found between $\mathrm{CO}$ yield and cellulose content $(R=0.952, P<0.01)$ and between $\mathrm{CH}_{4}$ yield and cellulose content $(R=0.876, P<0.05)$. The strong positive relationship between $\mathrm{CO}$ yield and cellulose content is directly related to higher content of carbonyl groups in cellulose, which is consistent with results obtained by Qu et al. 


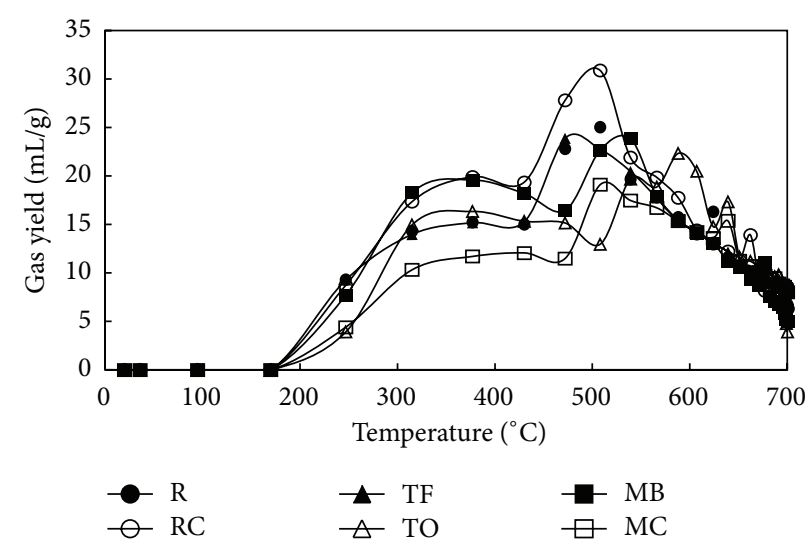

(a)

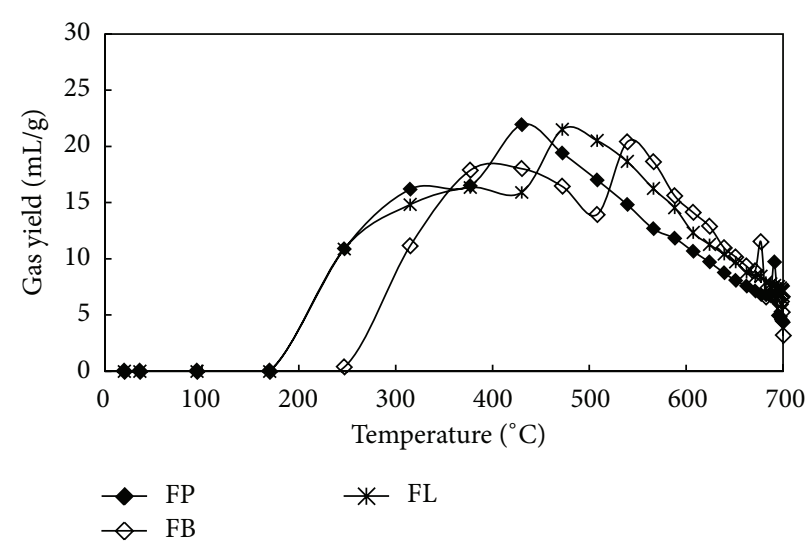

(b)

FIGURE 3: Evolution of gas released during pyrolysis of composts: (a) NHG and (b) HG as a function of temperature.

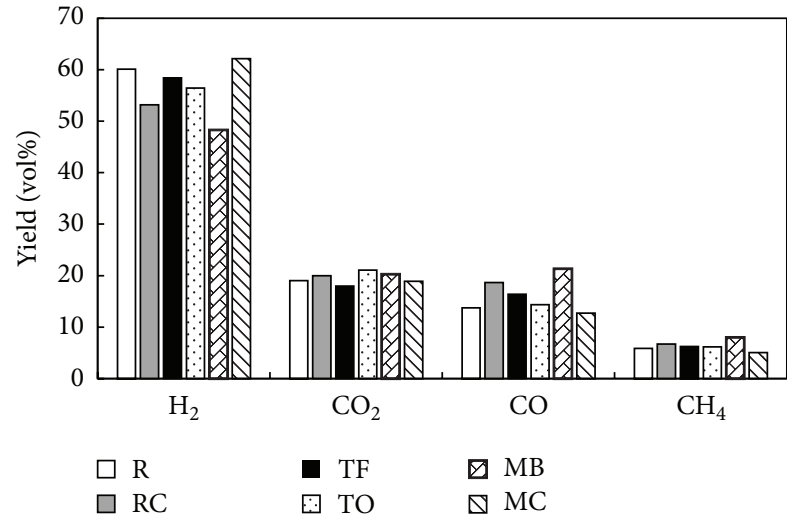

(a)

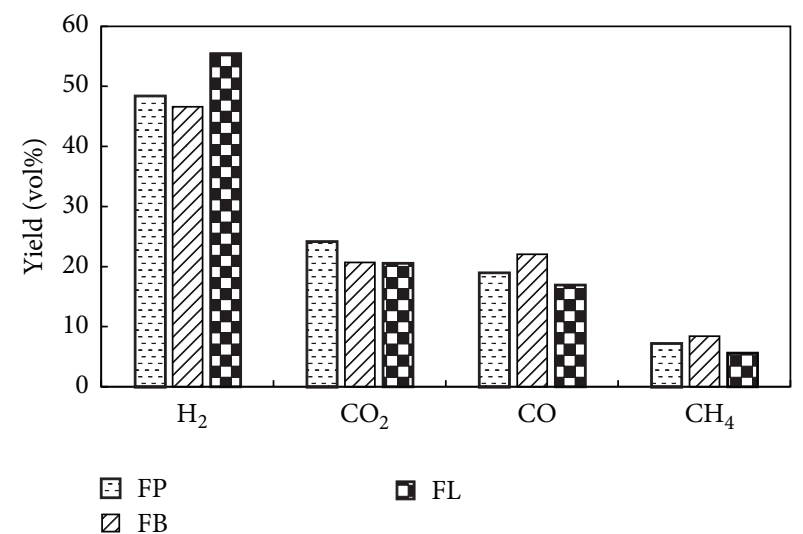

(b)

FIGURE 4: Yields of individual gaseous products from pyrolysis of (a) NHG composts and (b) $\mathrm{HG}$ composts at $700^{\circ} \mathrm{C}$ and $\mathrm{N}_{2}$ free-vol\%.

[28] and Yang et al. [29]. The exception to the observed correlations was observed for $\mathrm{CO}_{2}$ yield which was found to be unrelated to either biochemical composition or watersoluble alkali. Instead, a weaker and marginally significant correlation to one of the components of proximate analysis, moisture, was observed $(R=0.780, P<0.1)$, which is a further confirmation of presence of water-gas shift reaction.

The individual products yields trends observed for NHG composts were also observed for two out of three HG composts, namely, FP and FB (Figure 4(b)). The remaining compost, FL, resulted in the highest yield of $\mathrm{H}_{2}$ (55.43 vol\%) and the lowest yields of $\mathrm{CO}_{2}$ (20.58 vol\%), CO (16.95 vol\%), and $\mathrm{CH}_{4}$ (5.60 vol\%). The analogy of NHG composts cannot be, however, applied to these samples as the correlation between lignin and $\mathrm{K}$ contents was in the opposite direction $(R=-0.983)$ with a value which fell just shy of the statistical significance threshold $(P=0.127)$. A negative correlation between lignin and $\mathrm{K}$ was also reported by Fahmi et al. [40] who investigated the effect of alkali metals on pyrolysis of Lolium and Festuca independently. For this reason, the NHG and HG composts samples were also separated in this study when examining the possible relationships between gaseous product yields and composts composition. In addition, the correlations between individual products' $\left(\mathrm{H}_{2}, \mathrm{CO}\right.$, and $\left.\mathrm{CH}_{4}\right)$ yields and lignin content were no longer applicable and insignificant due to the small number of observations. The observed changes may, however, suggest that as much as both lignin and $\mathrm{K}$ contents affect the $\mathrm{H}_{2}$ formation during pyrolysis of NHG composts, in the case of HG composts, it may be $\mathrm{K}$ content that has the greatest influence on $\mathrm{H}_{2}$ production.

Figure 5 presents the evolution profiles of pyrolysis gaseous products of NHG composts (Figure 5(a)) and HG composts (Figure 5(b)) as a function of temperature. The products released at temperature below $450^{\circ} \mathrm{C}$ consisted mainly of $\mathrm{CO}_{2}, \mathrm{CO}$, and $\mathrm{CH}_{4}$ which is consistent with the prior literature [21]. A further increase of pyrolysis temperature changed the emission of pyrolysis gases as the yield of $\mathrm{CO}$ and $\mathrm{CO}_{2}$ began to decrease in expense of greater $\mathrm{H}_{2}$ and $\mathrm{CH}_{4}$ formation. The greatest discrepancies in the emission profiles of primary noncondensable gases were observed for $\mathrm{H}_{2}$ profiles. The differences occurred not only in the gas release temperature but in the shape of evolution profiles as 

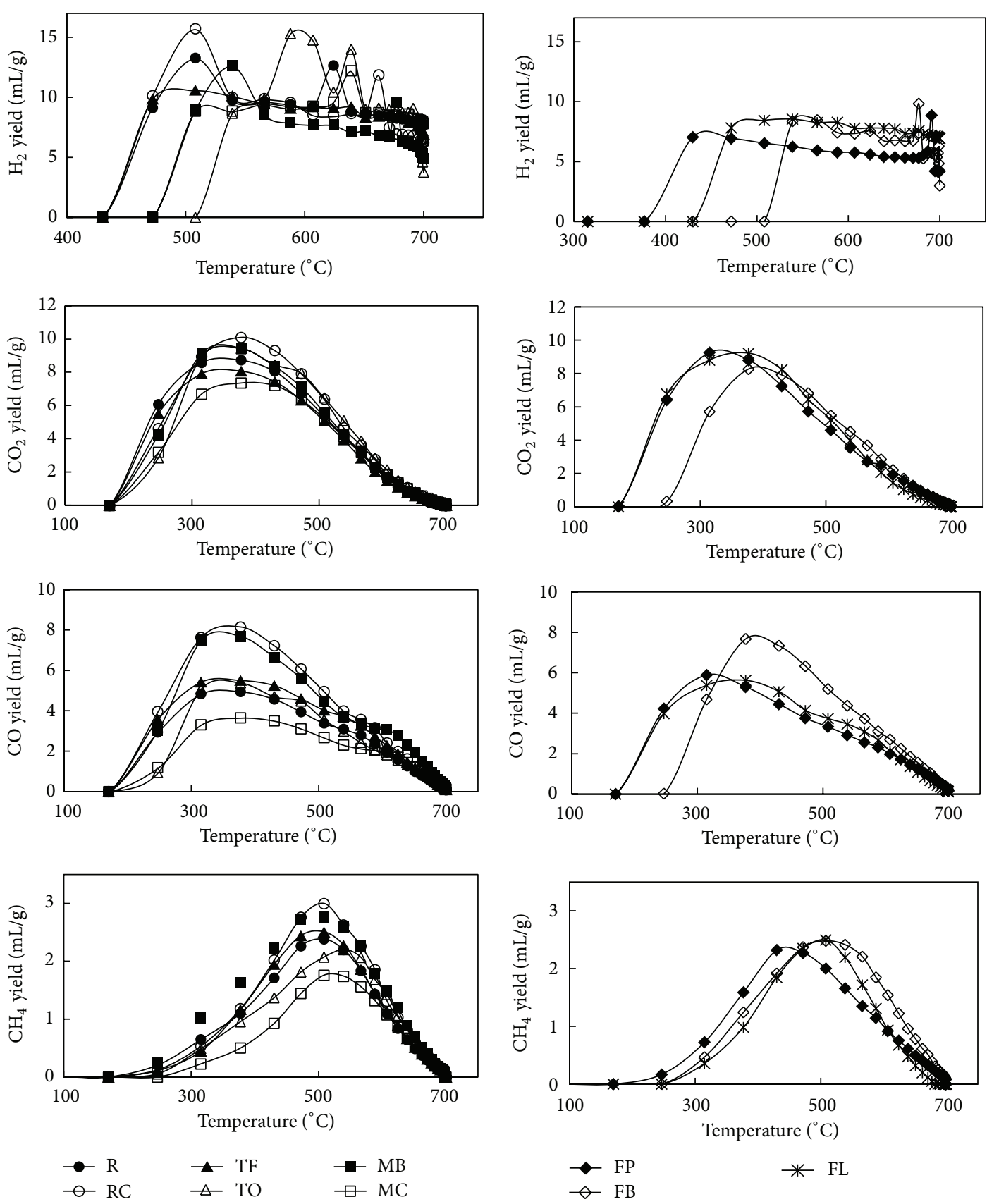

(a)

(b)

FIGURE 5: Evolution profiles of individual gaseous products from pyrolysis of (a) NHG composts and (b) HG composts.

well. The emission of $\mathrm{H}_{2}$ during pyrolysis of NHG composts began at $430^{\circ} \mathrm{C}\left(\mathrm{R}, \mathrm{RC}\right.$, and $\mathrm{TF}$ composts), $472^{\circ} \mathrm{C}$ (MC and $\mathrm{MB}$ composts), and $508^{\circ} \mathrm{C}$ (TO compost), whereas the release of $\mathrm{H}_{2}$ during pyrolysis of $\mathrm{HG}$ composts began at $377^{\circ} \mathrm{C}$ (FP compost), $430^{\circ} \mathrm{C}$ (FL compost), and $508^{\circ} \mathrm{C}$ (FB compost). The majority of NHG composts (R, RC, TO, and $\mathrm{MB}$ ) exhibited double-peak profiles with some shift of both the first peak maximum (observed in the $508-588^{\circ} \mathrm{C}$ range) and the second peak maximum (observed in the $624-677^{\circ} \mathrm{C}$ range). The maximum of the first peak is the highest and is attributed to cracking of $\mathrm{C}-\mathrm{H}$ bonds of lignin and cellulose and its shift is a consequence of a change of released temperature [29], whereas the second peak is smaller and is associated with pyrolytic reactions of lignin due to its higher content of aromatic ring (i.e., cracking and deformation of $\mathrm{C}=\mathrm{C}$ and $\mathrm{C}-\mathrm{H}$ bonds) and charring reactions $[29,31]$. The observed changes are also a further confirmation of the fact that the formation of $\mathrm{H}_{2}$ at temperature $>400^{\circ} \mathrm{C}$ is mostly contributed by pyrolysis of biochemical components, whereas the release of $\mathrm{H}_{2}$ at temperature $>500^{\circ} \mathrm{C}$ is mainly attributed to thermal degradation of lignin and the occurrence of charring reactions $[21,35,36]$. As aforementioned, these reactions are 
more pronounced in the energy grasses than in other biomass type materials (i.e., wood) due to a greater amount of alkali metals responsible for catalyzing these types of reactions [35, 36]. The remaining NHG composts, MC and TF, resulted in single-peak or no-peak evolution profiles, respectively. Similar $\mathrm{H}_{2}$ profiles were exhibited by HG compost; specifically, a single-peak profile was obtained for FP and FB composts, whereas a no-peak profile was obtained for FL compost. The resemblance between HG composts corresponds well with the profile obtained for TF compost since HG composts are a cross between Festuca (FT) and Lolium. The overall yield of formed $\mathrm{H}_{2}$ in these samples is also related to a combination of both pyrolytic reactions of biochemical compounds and charring reactions.

No significant discrepancies between NHG and HG composts were observed in the emission profiles of the remaining gaseous products. All samples displayed wide single-peak profiles and, in general, a starting point of emission at $170^{\circ} \mathrm{C}$. The shift of a starting point of emission to $247^{\circ} \mathrm{C}$ was only observed for $\mathrm{FB}$ compost for $\mathrm{CO}$ and $\mathrm{CO}_{2}$ evolution profiles. The majority of $\mathrm{CO}_{2}$ release took place in the temperature ranges of $250-450^{\circ} \mathrm{C}$ for FP and FL (hybrid grasses) composts, and $300-500^{\circ} \mathrm{C}$ for NHG and FB (hybrid grass) composts. This corresponds well with $\mathrm{CO}_{2}$ release from all biochemical components through cracking and reforming of carboxyl groups [28, 29, 41] and is in agreement with calculated Pearson's correlations (i.e., no single statistically significant relationship towards one particular biochemical component was observed). A reduction of $\mathrm{CO}_{2}$ emission at temperature $>500^{\circ} \mathrm{C}$ is likely due to secondary reactions of volatiles as temperature at this point has a limited influence $[21,42]$. A minor difference between both types of composts was observed in the emission of $\mathrm{CO}$. That is, a single evolution profile with a release of majority of the product in $300-500^{\circ} \mathrm{C}$ range was obtained for $\mathrm{RC}, \mathrm{MB}$ (nonhybrid grasses), and $\mathrm{FB}$ (hybrid grass) composts. The remaining samples exhibited a wider but shorter $\mathrm{CO}$ peak at temperature ranges of $300-500^{\circ} \mathrm{C}$ and $250-500^{\circ} \mathrm{C}$ with a break of possible second peak at $500-640^{\circ} \mathrm{C}$ range for $\mathrm{R}, \mathrm{TF}, \mathrm{TO}$, and $\mathrm{MC}$ (nonhybrid grasses) and FP and FL (hybrid grasses) composts, correspondingly. The $\mathrm{CO}$ emission is mainly attributed to cracking of carbonyl and carboxyl groups from cellulose [28, 29, 41]. The most constant evolution profile was obtained for $\mathrm{CH}_{4}$ as its emission focused mainly at a temperature range of $450-550^{\circ} \mathrm{C}$ and was attributed to cracking of methoxyl groups $[28,29,41]$.

3.3. Syngas Production. The high variability of $\mathrm{CO}$ and $\mathrm{H}_{2}$ yields led to gas mixtures with equally high variability of $\mathrm{H}_{2} / \mathrm{CO}$ ratios. Figure 6 presents total yield of formed syngas with respect to the particular $\mathrm{H}_{2} / \mathrm{CO}$ ratio, specifically, the total yield of syngas produced with $\mathrm{H}_{2} / \mathrm{CO}=2$ used in Fischer-Tropsch and methanol syntheses and with $\mathrm{H}_{2} / \mathrm{CO}$ $=3$ used for synthetic natural gas production. All compost samples investigated resulted in syngas formation with $\mathrm{H}_{2} / \mathrm{CO}=2$. However, only five composts resulted in the production of syngas with $\mathrm{H}_{2} / \mathrm{CO}=3$ (i.e., $\mathrm{R}$, TF, TO, and $\mathrm{MC}$ composts obtained from nonhybrid grasses and FL

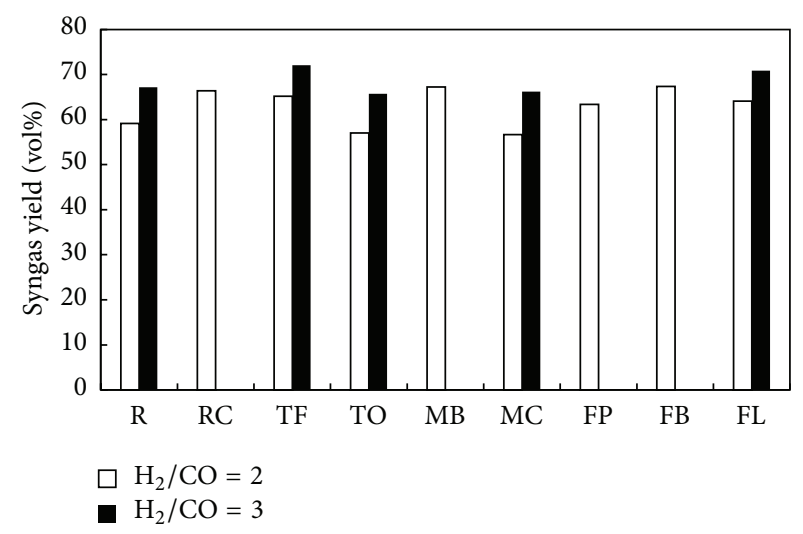

Figure 6: Total yield of syngas at $\mathrm{H}_{2} / \mathrm{CO}=2$ and $\mathrm{H}_{2} / \mathrm{CO}=3$.

compost from hybrid grass). The highest amount of syngas with $\mathrm{H}_{2} / \mathrm{CO}=2$ was obtained for $\mathrm{MB}$ (nonhybrid grass) and FB (hybrid grass) composts, 67.23 vol\% and 67.38 vol\%, respectively. These two composts also resulted in the lowest $\mathrm{H}_{2}$ and the highest $\mathrm{CO}$ yields, correspondingly, whereas the highest amount of syngas with $\mathrm{H}_{2} / \mathrm{CO}=3$ (72.10 vol\%) was obtained from pyrolysis of TF (nonhybrid grass) compost.

The change of $\mathrm{H}_{2} / \mathrm{CO}$ ratio with pyrolysis temperature is shown in Figure 7. In general, apart from two samples, TO and $\mathrm{MC}$ composts, all composts displayed a gradual increase of $\mathrm{H}_{2} / \mathrm{CO}$ ratio with a pyrolysis temperature increase up to $650^{\circ} \mathrm{C}$. A further increase of pyrolysis temperature resulted in a steep $\mathrm{H}_{2} / \mathrm{CO}$ ratio increase which corresponds well with obtained $\mathrm{CO}$ evolution profiles and indicates mostly $\mathrm{H}_{2}$ generation. The TO and MC composts exhibited a more abrupt increase of $\mathrm{H}_{2} / \mathrm{CO}$ ratio with a pyrolysis temperature increase, which can indicate a higher rate of charring and cracking reactions for these particular samples. It was not a surprise that in regard to the specific value of $\mathrm{H}_{2} / \mathrm{CO}$ ratio, these two composts reached this value at the lowest temperature. That is, a $\mathrm{H}_{2} / \mathrm{CO}$ ratio $=2$ was obtained at 624 and $639^{\circ} \mathrm{C}$, whereas a $\mathrm{H}_{2} / \mathrm{CO}$ ratio $=3$ was obtained at 673 and $684^{\circ} \mathrm{C}$, for $\mathrm{MC}$ and $\mathrm{TO}$ composts, respectively. Among samples for which $\mathrm{H}_{2} / \mathrm{CO}$ ratios increased gradually, only one sample in particular reached the required $\mathrm{H}_{2} / \mathrm{CO}$ ratio at a similar temperature range. Specifically, $\mathrm{R}$ composts resulted in $\mathrm{H}_{2} / \mathrm{CO}$ ratio $=2$ at $624^{\circ} \mathrm{C}$ and in $\mathrm{H}_{2} / \mathrm{CO}$ ratio $=3$ at $682^{\circ} \mathrm{C}$. The remaining samples reached the essential $\mathrm{H}_{2} / \mathrm{CO}$ ratio in higher temperature ranges of $660-700^{\circ} \mathrm{C}$ and $695-700^{\circ} \mathrm{C}$ for $\mathrm{H}_{2} / \mathrm{CO}$ ratio $=2$ and $\mathrm{H}_{2} / \mathrm{CO}$ ratio $=3$, correspondingly. The temperature necessary to obtain the specific $\mathrm{H}_{2} / \mathrm{CO}$ ratios increased, therefore, in the following composts type order: (i) $\mathrm{H}_{2} / \mathrm{CO}=2: \mathrm{R}, \mathrm{MC}<\mathrm{TO}<\mathrm{TF}<\mathrm{FL}<\mathrm{RC}<\mathrm{FP}<\mathrm{MB}<\mathrm{FB}$ and (ii) $\mathrm{H}_{2} / \mathrm{CO}=3$ : $\mathrm{MC}<\mathrm{R}<\mathrm{TO}<\mathrm{TF}<\mathrm{FL}$.

3.4. Pyrolysis Gas HHV. The HHVs of pyrolysis gas with respect to its total yield and syngas yield are displayed in Figure 8. The size of the bubble represents the HHV expressed in $\mathrm{MJ} / \mathrm{kg}_{\text {gas }}$ obtained at a specific pyrolysis temperature at which an explicit $\mathrm{H}_{2} / \mathrm{CO}$ ratio was reached. Figure $8(\mathrm{a})$ shows the HHVs of pyrolysis gas obtained at $\mathrm{H}_{2} / \mathrm{CO}=2$, and 


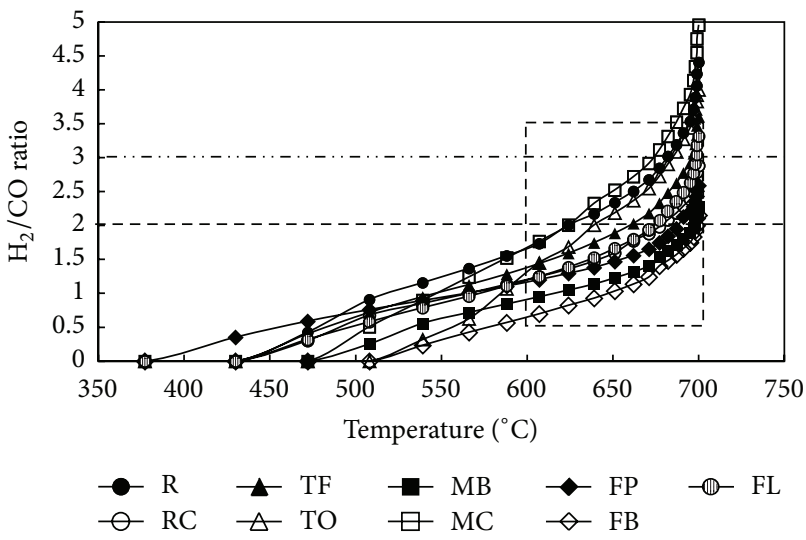

(a)

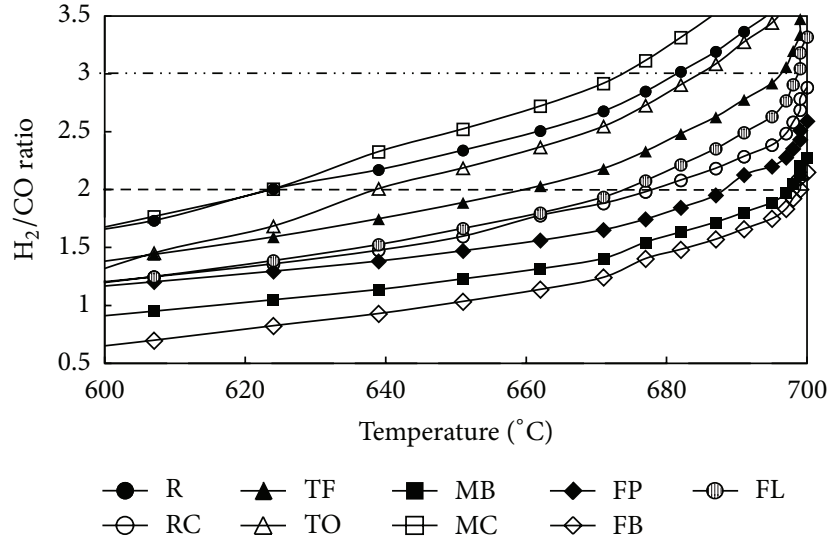

(b)

Figure 7: $\mathrm{H}_{2} / \mathrm{CO}$ ratio as a function of temperature.

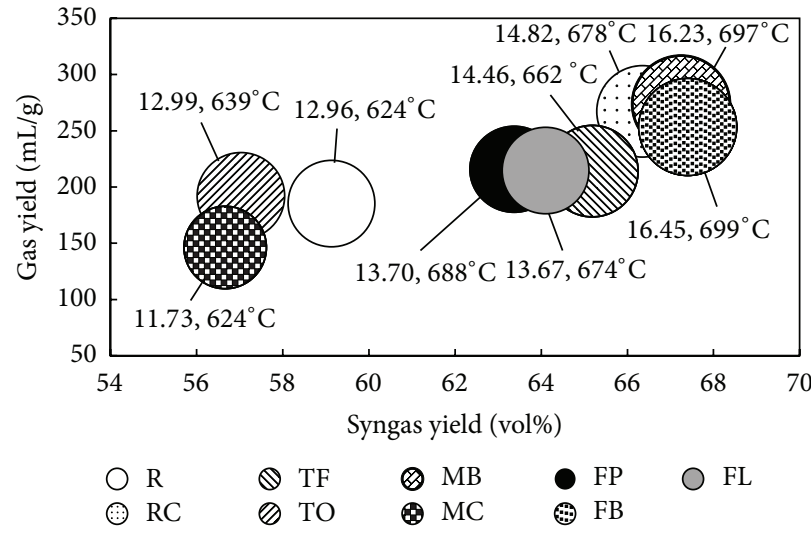

(a)

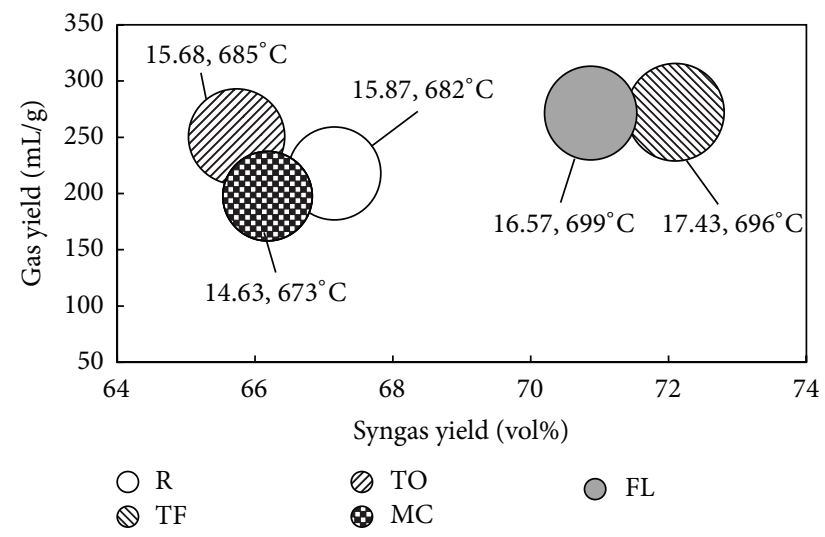

(b)

FIGURE 8: HHVs of pyrolysis gas with respect to its yield and syngas yield: (a) $\mathrm{H}_{2} / \mathrm{CO}=2$ and (b) $\mathrm{H}_{2} / \mathrm{CO}=3$.

Figure 8 (b) shows the HHVs of pyrolysis gas obtained at $\mathrm{H}_{2} / \mathrm{CO}=3$. The HHV was directly associated with pyrolysis temperature; that is, as pyrolysis temperature increased, the $\mathrm{HHV}$ increased as well. As a consequence, the optimal HHV was reached at the highest syngas yield, which is consistent with the prior literature $[21,43,44]$, but not at the highest gas yield. For example, the highest $\mathrm{HHV}$ at $\mathrm{H}_{2} / \mathrm{CO}=2$ in the amount of 16.23 and $16.45 \mathrm{MJ} / \mathrm{kg}_{\text {gas }}$ was obtained for $\mathrm{MB}$ (nonhybrid grass) and FB (hybrid grass) composts, respectively, which also resulted in the highest syngas formation; however, they exhibited one of the lowest total gas yields, whereas the highest $\mathrm{HHV}$ at $\mathrm{H}_{2} / \mathrm{CO}=3$ was obtained for $\mathrm{TF}$ (nonhybrid grass) and FL (hybrid grass) composts, 16.57 and $17.43 \mathrm{MJ} / \mathrm{kg}_{\text {gas }}$, correspondingly, which corresponded to the highest syngas yield and third highest total gas yield for TF compost and the highest total gas yield and second highest syngas yield for FL compost. It is important to note that these values are only marginally lower than the HHVs obtained for raw materials (i.e., by $5.69 \%, 9.17 \%, 4.22 \%$, and $4.28 \%$ for $\mathrm{MB}, \mathrm{FB}, \mathrm{TF}$, and FL composts, resp.) and are comparable to those obtained from pyrolysis of wood or coir pith $[39,45]$. The HHVs of pyrolysis gas reported in the literature are significantly lower (4-12 MJ/ $\left.\mathrm{kg}_{\text {gas }}\right)$ and are given mainly for products obtained from pyrolysis of grasses rather than grass composts [12, 42, 43, 46]. The significant increase of observed pyrolysis gases HHV is likely due to (i) composting process which results in lignin enriched material, ipso facto greater $\mathrm{H}_{2}$ formation, and (ii) sawdust addition to the composting process [47].

\section{Conclusions}

The syngas generation from pyrolysis of nine composts was investigated in this study. Composts were divided into two groups: composts obtained from nonhybrid perennial grasses and composts obtained from hybrid perennial grasses. The pyrolysis experiments were conducted in a fixed bed reactor to a final temperature of $700^{\circ} \mathrm{C}$. Apart from compost obtained from tall oatgrass which exhibited the evolution gas profile with three peaks, all the remaining materials displayed two-peak evolution profiles indicating formation of gases based on two main processes: (i) thermal decomposition of biochemical components and (ii) secondary reactions of 
char. A distinction between NHG and HG composts was observed for the evolution profiles of individual gaseous products, in particular $\mathrm{H}_{2}$. HG composts resulted in no-peak evolution profiles, whereas NHG composts displayed twopeak and one-peak distributions. A no-peak distribution was only observed for one of the NHG composts made from tall fescue which belongs to the same genus as hybrid grasses. The remaining gaseous products $\left(\mathrm{CO}, \mathrm{CO}_{2}\right.$, and $\left.\mathrm{CH}_{4}\right)$ did not result in significant changes in emission profiles. It was found that all examined composts resulted in $\mathrm{H}_{2} / \mathrm{CO}$ necessary for future utilization in the amount of 2 and only five of the studied composts resulted in $\mathrm{H}_{2} / \mathrm{CO}=3$. A close relationship was established between $\mathrm{H}_{2}$, CO, and syngas yields, $\mathrm{HHV}$ of pyrolysis gas, and temperature required to obtain the essential $\mathrm{H}_{2} / \mathrm{CO}$ ratio. Specifically, composts obtaining the highest $\mathrm{H}_{2}$ yield resulted in the lowest $\mathrm{CO}$ yield, following the lowest syngas yield, $\mathrm{HHV}$, and temperature required to obtain the specific $\mathrm{H}_{2} / \mathrm{CO}$ ratio, whereas composts obtaining the lowest $\mathrm{H}_{2}$ yield resulted in the highest $\mathrm{CO}$ yield, following the highest syngas yield, $\mathrm{HHV}$, and temperature required to obtain the essential $\mathrm{H}_{2} / \mathrm{CO}$ ratio. It was also found that the formation of $\mathrm{H}_{2}$ was significantly correlated with lignin and $\mathrm{K}$ contents for nonhybrid grass. That is, strong positive correlations were obtained between (i) lignin and $\mathrm{K}$ contents, (ii) lignin content and $\mathrm{H}_{2}$ yield, and (iii) $\mathrm{K}$ content and $\mathrm{H}_{2}$ yield. Comparatively, a negative correlation (that just barely fell outside statistical significance) was observed for HG composts between lignin and $\mathrm{K}$ contents. The remaining correlations (i.e. between lignin content and $\mathrm{H}_{2}$ yield and between $\mathrm{K}$ content and $\mathrm{H}_{2}$ yield) were not statistically significant. Remarkable results were also obtained for HHV of pyrolysis gas. Specifically, values close to the HHVs of raw materials, 16.23, 17.43, and $16.45 \mathrm{MJ} / \mathrm{kg}$, were calculated for composts obtained from mountain brome, tall fescue, and festulolium Becva composts, respectively. The increase was attributed to the composting process (i.e., an increase of lignin content) and sawdust addition. Finally, the composts made from mountain brome grass and hybrid Becva were recognized as the optimal materials for fuel/energy generation due to their (i) highest syngas formation and (ii) highest HHV.

\section{Conflict of Interests}

The authors declare that there is no conflict of interests regarding the publication of this paper.

\section{Acknowledgments}

This research was supported by the Czech Republic Ministry of Education, Youth and Sport, and the Centre ENET research project, Reg. no. CZ.1.05/2.1.00/03.0069, and the Czech Republic Ministry of Agriculture research project, Reg. no. MZ QI101C246, elaborated in the framework of the project New Creative Teams in Priorities of Scientific Research, Reg. no. CZ.1.07/2.3.00/30.0055, supported by Operational Programme Education for Competitiveness, and cofinanced by the European Social Fund and the state budget of the Czech Republic.

\section{References}

[1] European Commission, Report from the Commission to the European Parliament, the Council, the European Economic and Social Committee and the Committee of the Regions, 2013.

[2] R. E. H. Sims, A. Hastings, B. Schlamadinger, G. Taylor, and P. Smith, "Energy crops: current status and future prospects," Global Change Biology, vol. 12, no. 11, pp. 2054-2076, 2006.

[3] H. Haberl, K. Erb, F. Krausmann et al., "Global bioenergy potentials from agricultural land in 2050: sensitivity to climate change, diets and yields," Biomass and Bioenergy, vol. 35, no. 12, pp. 4753-4769, 2011.

[4] Commission of the European Communities, "Report from the Commission to the Council on the review of the energy crops scheme," 2006, http://iet.jrc.ec.europa.eu/remea/sites/remea/ files/files/documents/com_2006_500_energy_crops_scheme.pdf.

[5] L. Potter, M. J. Bingham, M. G. Baker, and S. P. Long, "The potential of two perennial $\mathrm{C}_{4}$ grasses and a perennial $\mathrm{C}_{4}$ sedge as ligno-cellulosic fuel crops in N. W. Europe. Crop establishment and yields in E. England," Annals of Botany, vol. 76, no. 5, pp. 513-520, 1995.

[6] M. Rahman, S. B. Mostafiz, J. V. Paatero, and R. Lahdelama, "Extension of energy crops on surplus agricultural lands: a potentially viable option in developing countries while fossil fuel reserves are diminishing," Renewable and Sustainable Energy Reviews, vol. 29, pp. 108-119, 2014.

[7] C. Wrobel, B. E. Coulman, and D. L. Smith, "The potential use of reed canarygrass (Phalaris arundinacea L.) as a biofuel crop," Acta Agriculturae Scandinavica B: Soil and Plant Science, vol. 59, no. 1, pp. 1-18, 2009.

[8] Czech Statistical Office, "Harvest of permanent grassland in hay in 2012 by regions," 2013, http://www.czso.cz/csu/2013edicniplan.nsf/engt/1000218C20/\$File/21021326.pdf.

[9] Czech Statistical Office, "Agriculture-3rd quarter of 2013. Meat production at the last year level, agricultural producer prices increased," 2013, http://www.czso.cz/csu/csu.nsf/enginformace/czem103113.doc.

[10] A. G. Barneto, J. A. Carmona, and M. Jesús Díaz Blanco, "Effect of the previous composting on volatiles production during biomass pyrolysis," Journal of Physical Chemistry A, vol. 114, no. 11, pp. 3756-3763, 2010.

[11] R. C. Baliban, J. A. Elia, V. Weekman, and C. A. Floudas, "Process synthesis of hybrid coal, biomass, and natural gas to liquids via Fischer-Tropsch synthesis, ZSM-5 catalytic conversion, methanol synthesis, methanol-to-gasoline, and methanolto-olefins/distillate technologies," Computers \& Chemical Engineering, vol. 47, pp. 29-56, 2012.

[12] A. A. Boateng, K. B. Hicks, and K. P. Vogel, "Pyrolysis of switchgrass (Panicum virgatum) harvested at several stages of maturity," Journal of Analytical and Applied Pyrolysis, vol. 75, no. 2, pp. 55-64, 2006.

[13] A. Moutsoglou, "A comparison of prairie cordgrass and switchgrass as a biomass for syngas production," Fuel, vol. 95, pp. 573$577,2012$.

[14] A. Gomez-Barea, S. Nilsson, F. V. Barrero, and M. Campoy, "Devolatilization of wood and wastes in fluidized bed," Fuel Processing Technology, vol. 91, no. 11, pp. 1624-1633, 2010.

[15] S. Li, S. Xu, S. Liu, C. Yang, and Q. Lu, "Fast pyrolysis of biomass in free-fall reactor for hydrogen-rich gas," Fuel Processing Technology, vol. 85, no. 8-10, pp. 1201-1211, 2004.

[16] P. Chaiwatanodom, S. Vivanpatarakij, and S. Assabumrungrat, "Thermodynamic analysis of biomass gasification with $\mathrm{CO}_{2}$ 
recycle for synthesis gas production," Applied Energy, vol. 114, pp. 10-17, 2014.

[17] Y. Bai, Y. Wang, S. Zhu, L. Yan, F. Li, and K. Xie, "Synergistic effect between $\mathrm{CO}_{2}$ and $\mathrm{H}_{2} \mathrm{O}$ on reactivity during coal chars gasification," Fuel, vol. 126, pp. 1-7, 2014.

[18] M. J. A. Tijmensen, A. P. C. Faaij, C. N. Hamelinck, and M. R. M. Van Hardeveld, "Exploration of the possibilities for production of Fischer Tropsch liquids and power via biomass gasification," Biomass and Bioenergy, vol. 23, no. 2, pp. 129-152, 2002.

[19] M. Widyawati, T. L. Church, N. H. Florin, and A. T. Harris, "Hydrogen synthesis from biomass pyrolysis with in situ carbon dioxide capture using calcium oxide," International Journal of Hydrogen Energy, vol. 36, no. 8, pp. 4800-4813, 2011.

[20] A. Domínguez, J. A. Menéndez, Y. Fernández et al., "Conventional and microwave induced pyrolysis of coffee hulls for the production of a hydrogen rich fuel gas," Journal of Analytical and Applied Pyrolysis, vol. 79, no. 1-2, pp. 128-135, 2007.

[21] D. Neves, H. Thunman, A. Matos, L. Tarelho, and A. GómezBarea, "Characterization and prediction of biomass pyrolysis products," Progress in Energy and Combustion Science, vol. 37, no. 5, pp. 611-630, 2011.

[22] A. Dufour, P. Girods, E. Masson, Y. Rogaume, and A. Zoulalian, "Synthesis gas production by biomass pyrolysis: effect of reactor temperature on product distribution," International Journal of Hydrogen Energy, vol. 34, no. 4, pp. 1726-1734, 2009.

[23] A. G. Barneto, J. A. Carmona, J. A. Conesa Ferrer, and M. J. Díaz Blanco, "Kinetic study on the thermal degradation of a biomass and its compost: composting effect on hydrogen production," Fuel, vol. 89, no. 2, pp. 462-473, 2010.

[24] A. G. Barneto, J. A. Carmona, A. Gálvez, and J. A. Conesa, "Effects of the composting and the heating rate on biomass gasification," Energy \& Fuels, vol. 23, no. 2, pp. 951-957, 2009.

[25] M. P. Bernal, J. A. Alburquerque, and R. Moral, "Composting of animal manures and chemical criteria for compost maturity assessment: a review," Bioresource Technology, vol. 100, no. 22, pp. 5444-5453, 2009.

[26] D. Plachá, H. Raclavská, M. Kučerova, and J. Kuchařova, "Volatile fatty acid evolution in biomass mixture composts prepared in open and closed bioreactors," Waste Management, vol. 33, no. 5, pp. 1104-1112, 2013.

[27] M. Blanco and G. Almendros, "Maturity assessment of wheat straw composts by thermogravimetric analysis," Journal of Agricultural and Food Chemistry, vol. 42, no. 11, pp. 2454-2459, 1994.

[28] T. Qu, W. Guo, L. Shen, J. Xiao, and K. Zhao, "Experimental study of biomass pyrolysis based on three major components: hemicellulose, cellulose, and lignin," Industrial and Engineering Chemistry Research, vol. 50, no. 18, pp. 10424-10433, 2011.

[29] H. Yang, R. Yan, H. Chen, D. H. Lee, and C. Zheng, "Characteristics of hemicellulose, cellulose and lignin pyrolysis," Fuel, vol. 86, no. 12-13, pp. 1781-1788, 2007.

[30] H. Yang, R. Yan, H. Chen, C. Zheng, D. H. Lee, and D. T. Liang, "In-depth investigation of biomass pyrolysis based on three major components: hemicellulose, cellulose and lignin," Energy \& Fuels, vol. 20, no. 1, pp. 388-393, 2006.

[31] A. G. Barneto, J. A. Carmona, J. E. M. Alfonso, and J. A. C. Ferrer, "Use of thermogravimetry/mass spectrometry analysis to explain the origin of volatiles produced during biomass pyrolysis," Industrial and Engineering Chemistry Research, vol. 48, no. 15, pp. 7430-7436, 2009.
[32] F. Collard, J. Blin, A. Bensakhria, and J. Valette, "Influence of impregnated metal on the pyrolysis conversion of biomass constituents," Journal of Analytical and Applied Pyrolysis, vol. 95, pp. 213-226, 2012.

[33] F. Kačík and R. Solár, Analytická chémia dreva, Technical University in Zvolen, Zvolen, Slovakia, 2000.

[34] R. S. Swift, "Organic matter characterization," in Methods of Soil Analysis, Part 3 Chemical Methods, D. L. Sparks, A. L. Page, P. A. Helmke et al., Eds., pp. 1011-1069, Soil Science Society of America and American Society of Agronomy, Madison, Wis, USA, 1996.

[35] C. J. Gómez, E. Mészáros, E. Jakab, E. Velo, and L. Puigjaner, "Thermogravimetry/mass spectrometry study of woody residues and an herbaceous biomass crop using PCA techniques," Journal of Analytical and Applied Pyrolysis, vol. 80, no. 2, pp. 416-426, 2007.

[36] R. A. Khalil, E. Mészáros, M. G. Grønli et al., “Thermal analysis of energy crops: part I: the applicability of a macrothermobalance for biomass studies," Journal of Analytical and Applied Pyrolysis, vol. 81, no. 1, pp. 52-59, 2008.

[37] K. Raveendran, A. Ganesh, and K. C. Khilar, "Pyrolysis characteristics of biomass and biomass components," Fuel, vol. 75, no. 8, pp. 987-998, 1996.

[38] C. Couhert, J. Commandre, and S. Salvador, "Is it possible to predict gas yields of any biomass after rapid pyrolysis at high temperature from its composition in cellulose, hemicellulose and lignin?" Fuel, vol. 88, no. 3, pp. 408-417, 2009.

[39] K. Raveendran, A. Ganesh, and K. C. Khilar, "Influence of mineral matter on biomass pyrolysis characteristics," Fuel, vol. 74, no. 12, pp. 1812-1822, 1995.

[40] R. Fahmi, A. V. Bridgwater, L. I. Darvell et al., "The effect of alkali metals on combustion and pyrolysis of Lolium and Festuca grasses, switchgrass and willow," Fuel, vol. 86, no. 10-11, pp. 1560-1569, 2007.

[41] L. Jiang, S. Hu, L. Sun et al., "Influence of different demineralization treatments on physicochemical structure and thermal degradation of biomass," Bioresource Technology, vol. 146, pp. 254-260, 2013.

[42] A. A. Boateng, W. F. Anderson, and J. G. Phillips, "Bermudagrass for biofuels: effect of two genotypes on pyrolysis product yield," Energy and Fuels, vol. 21, no. 2, pp. 1183-1187, 2007.

[43] A. A. Boateng, H. G. Jung, and P. R. Adler, "Pyrolysis of energy crops including alfalfa stems, reed canarygrass, and eastern gamagrass," Fuel, vol. 85, no. 17-18, pp. 2450-2457, 2006.

[44] D. Beneroso, J. M. Bermúdez, A. Arenillas, and J. A. Menéndez, "Microwave pyrolysis of microalgae for high syngas production," Bioresource Technology, vol. 144, pp. 240-246, 2013.

[45] K. Raveendran and A. Ganesh, "Heating value of biomass and biomass pyrolysis products," Fuel, vol. 75, no. 15, pp. 1715-1720, 1996.

[46] J. A. Conesa and A. Domene, "Synthesis gas production from various biomass feedstocks," AIMS Energy, vol. 1, pp. 17-27, 2013.

[47] S. M. Troy, T. Nolan, J. J. Leahy, P. G. Lawlor, M. G. Healy, and W. Kwapinski, "Effect of sawdust addition and composting of feedstock on renewable energy and biochar production from pyrolysis of anaerobically digested pig manure," Biomass \& Bioenergy, vol. 49, pp. 1-9, 2013. 


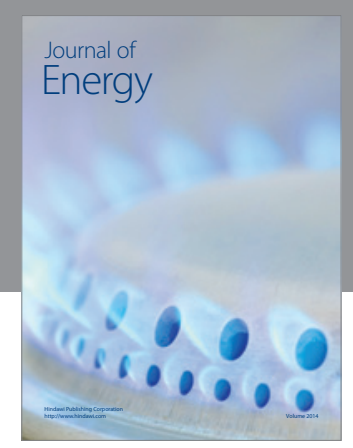

Journal of

Industrial Engineering
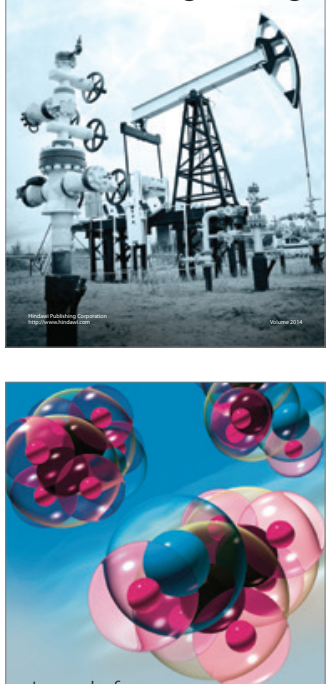

Fuels
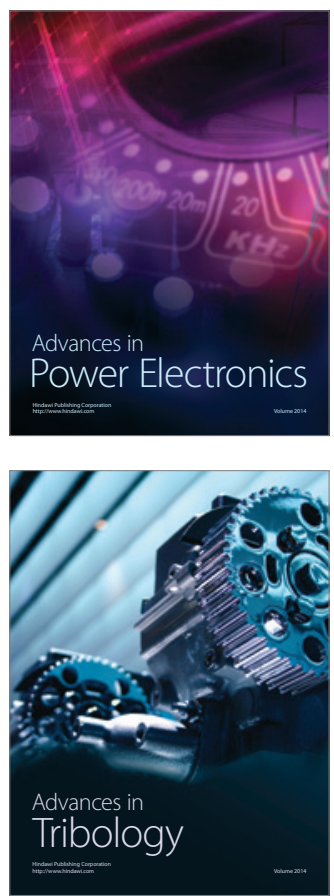

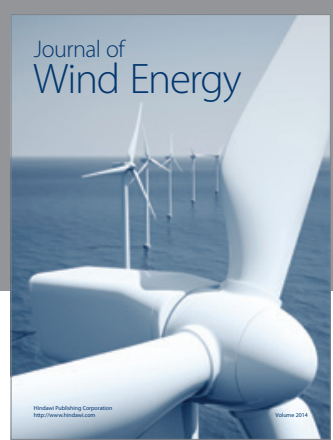

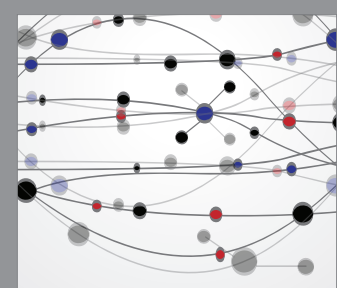

The Scientific World Journal

Submit your manuscripts at http://www.hindawi.com

Journal of

Structures
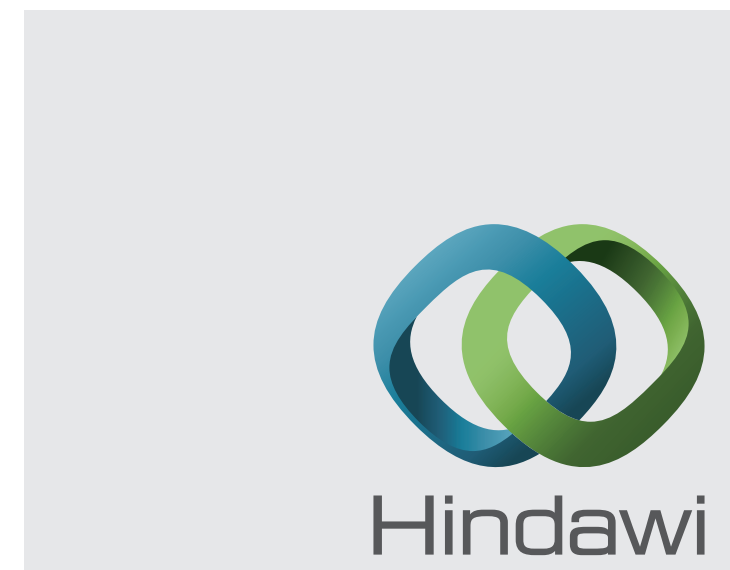

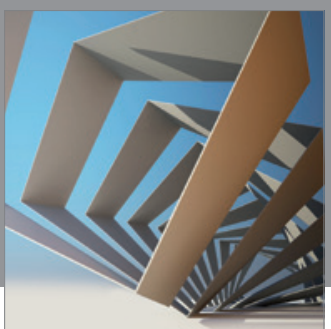

Rotating

Machinery
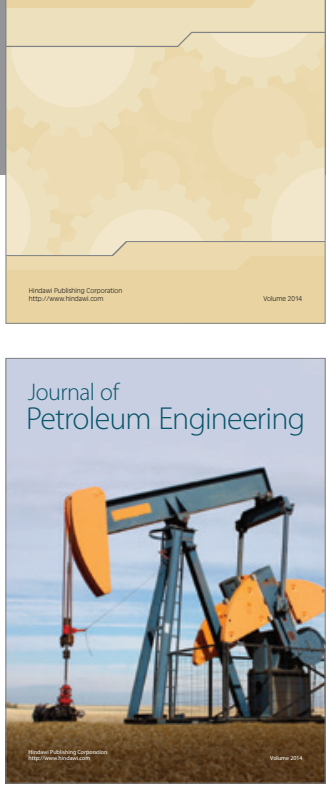

Journal of

Solar Energy
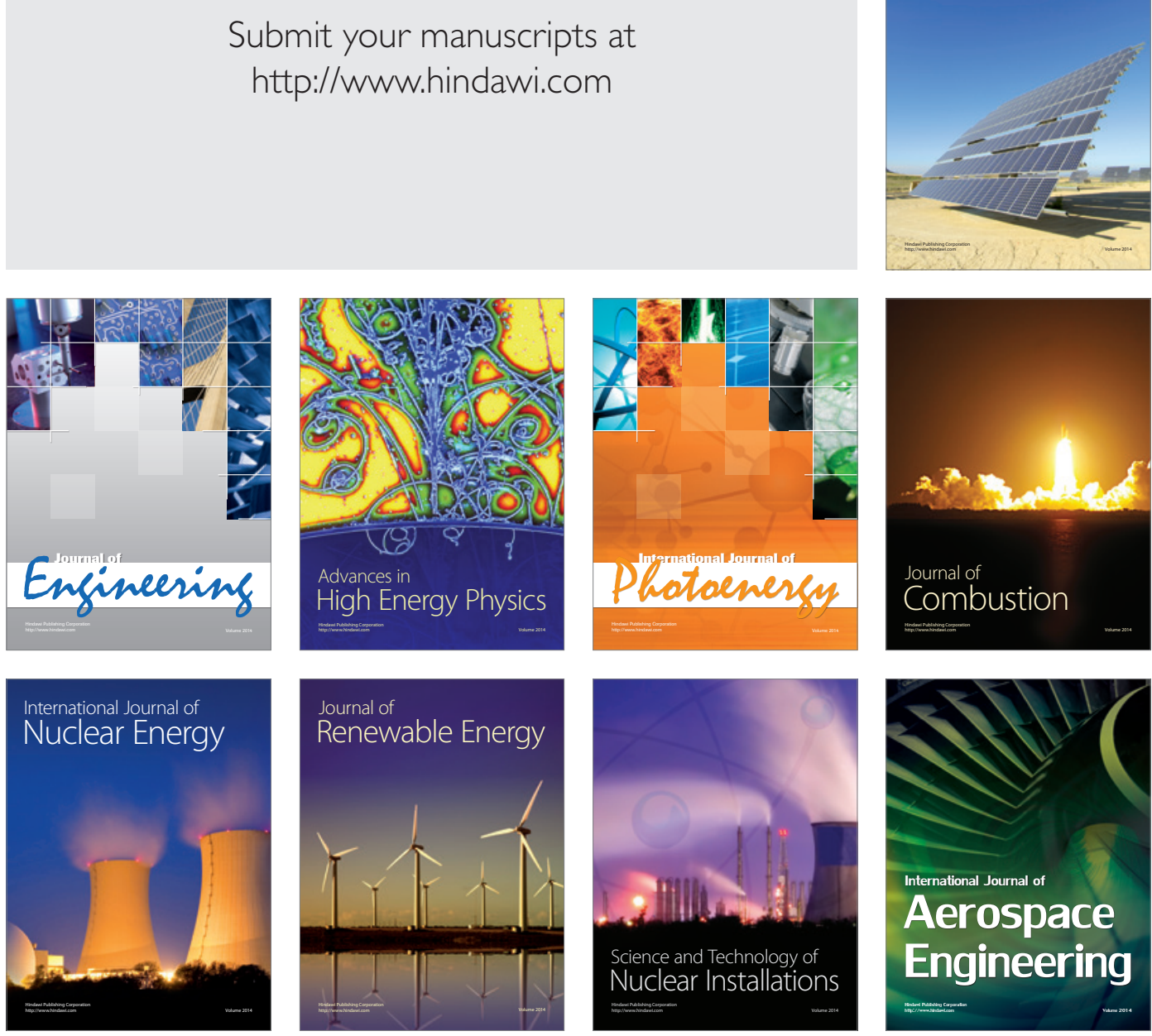